\title{
An unusual cause of forefoot pain: diagnosis and discussion
}

\author{
Alper Deveci • Onder M. Delialioglu • Bulent Daglar • \\ Sahap C. Tunç • Barıs Birinci • Kenan Bayrakci • \\ Esra Ersoy • Ugur Gunel
}

Published online: 13 May 2009

(C) ISS 2009

\section{Diagnosis}

Osteoid osteoma (OO).

\section{Discussion}

Osteoid osteoma is a relatively uncommon osteoblastic lesion of the bone that accounts for approximately $10 \%$ of all benign bone tumors and occurs predominantly in children and young adults, with a male-to-female ratio of $3: 1[1,2]$. More than half of osteoid osteomas occur in the femur and tibia, and the proximal femur is by far the most common location [2]. Its incidence in the small bones of the foot ranges from $2 \%$ to $11 \%$, with the talus being the most common site of pedal involvement $[2,3]$. No case

The case presentation can be found at doi: $10.1007 / \mathrm{s} 00256-009$ 0710-1

\footnotetext{
A. Deveci $\cdot$ S. C. Tunç $\cdot$ B. Birinci

Department of Orthopaedic Surgery,

Lokman Hekim Sincan Hospital,

Ankara, Turkey

O. M. Delialioglu • B. Daglar · K. Bayrakci - U. Gunel

Department of Orthopaedic Surgery,

Ankara Numune Training and Research Hospital,

Ankara, Turkey

E. Ersoy

Department of Pathology, Lokman Hekim Sincan Hospital,

Ankara, Turkey

A. Deveci $(\square)$

6.Etap Atakent Sitesi G2 Blok no:5/39,

Eryaman, Ankara, Turkey

e-mail: alper_deveci@yahoo.com
}

specifically involving the fibular sesamoid has been reported in the literature. Except for its location, this case presents a classic history of OO, occurring in a 19-year-old woman and producing nighttime pain, relieved to some extent by salicylates.

The classic presentation is a single small $(<1.5 \mathrm{~cm})$ round or oval lytic focus, which may contain a variable amount of ossification with a zone of reactive sclerosis [4].

The radiographic appearance of OO may be classified according to its location into cortical, cancellous, and subperiostal regions of bone [1,5-7]. Typically, the tumor is cortical, comprising a small area of radiolucency less than $1 \mathrm{~cm}$ in diameter, subcortically placed, and associated with dense adjacent bone sclerosis and periostal reaction. The cancellous variety of $\mathrm{OO}$ displays less radiographic sclerosis than does the cortical type. The cancellous and subperiostal varieties have been reported to be more prevalent in the small bones of the hand and foot [7]. In our case there was a radiolucent nidus surrounded by an illdefined sclerotic rim, with central calcification as in the cancellous subtype.

In patients with $\mathrm{OO}$ computed tomography demonstrates the radiolucent nidus with a smooth inner surface, and, in some cases, a radiodense center can be visualized, as in our case. This central calcification is suggested to represent the osteoblastic center of the lesion [8].

Bone scanning almost always produces positive findings and is valuable when plain radiographs are equivocal. A typical 'hot spot' is shown, due to intense radionuclide uptake by the lesion, as in our case [9].

The histopathologic appearance of the nidus may vary, depending on the maturity of the lesion [2]. The pathologic appearance of the nidus is of a small, round, mass of tissue which can be either soft or sclerotic, red, and surrounded by normal or sclerotic bone. Microscopic 
examination shows an interlacing network of osteoid trabeculae with vascular, fibrous, connective tissue, benign multinucleated giant cells, and well-differentiated osteoblasts. Cartilage is never present in the lesion [2]. The size of the nidus is usually $1 \mathrm{~cm}$, and it is surrounded by normal or sclerotic bone [2]. In our pathology specimen no sclerotic bone surrounding the nidus can be seen. The microscopic findings were consistent with these descriptions, confirming the diagnosis.

The histological appearance of osteoblastoma is very close to that of OO. Osteoid trabeculae are usually broader and longer, and the lesion is more vascular than an OO. Osteoblastoma appears in younger patients and is usually larger than an $\mathrm{OO}(>1.5-2 \mathrm{~cm})$ and is less painful $[10,11]$. It may demonstrate aggressive local behavior [10]. Osteoblastoma often arises from the medullary bone and exhibits a greater predilection for the posterior elements of the spine [4].

En bloc resection, curettage and radiofrequency ablation are surgical treatment modalities for OO [9].

This case reaffirms the possibility that OO may involve any bone. Involvement of the fibular sesamoid can be easily confused with tenosynovitis and metatarsalgia of the foot and chronic osteomyelitis. A high index of suspicion and a detailed history of the patient are required by the surgeon in order to minimize the diagnostic delay of this potentially treatable condition.

\section{References}

1. Barca F, Acciaro AL, Recchioni MD. Osteoid osteoma of the phalanx: enlargement of the toe- two case reports. Foot Ankle Int 1998; 19: 388-393.

2. Unni KK. Dahlin's bone tumors. General aspects and data on 11082 cases, 5th edn. New York: Lippincott-Raven; 1996.

3. Sproule JA, Khan F, Fogarty EE. Osteoid osteoma: painful enlargement of the second toe. Arch Orthop Trauma Surg 2004; 124: 354-356.

4. Resnick D, Kyriakos M, Greenway GD. Osteoid osteoma. In: Resnick D, ed. Diagnosis of bone and joint disorders, 3rd edn. Philadelphia: Saunders; 1995; p. 3629-3647.

5. Ekmekci P, Bostanci S, Erdogan N, Akcaboy B, Gurgey E. A painless subungual osteoid osteoma. Dermatol Surg 2001; 27: 764-765.

6. LaCroix ML, Thomas JR, Nicholas RW. Subperiostal osteoid osteoma of the distal phalanx of the fourth toe. Orthopedics 2001; 24: 695-696.

7. Meng QF, Watt I. Phalangeal osteoid osteoma. Br J Radiol 1989; 62: 321-325

8. Hoeffel JC, Lascombes P, Delgoffe C, Aymard B, Galloy MA. Osteoid osteoma of the rib: a case report. J Pediatr Surg 1993; 28: 738-740.

9. Di Gennaro GL, Lampasi M, Bosco A, Donzelli O. Osteoid osteoma of the distal thumb phalanx: a case report. Chir Organi Mov 2008; 92: 179-182.

10. Chiou YY, Rosenthal DI, Rosenberg AE. "Beaded" osteoid osteoma: a possible transition between solitary and multicentric tumor. Skeletal Radiol 2003; 32: 412-415.

11. Tourniaire J, Bossard D, Gleize B, Tavernier T, Bochu M. Case report 801: osteoid osteoma of the coccyx. Skeletal Radiol 1993; 22: $457-459$. 